Estonian Journal of Archaeology, 2005, 9, 1, 85-87

\title{
PIIRID LOODUSES JA KULTUURIS
}

\author{
Sander Tint ja Martti Veldi
}

Sander Tint, Tartu Ülikooli Geograafia Instituut, Vanemuise 46, 51014 Tartu, Eesti; meelt6iv@ut.ee Martti Veldi, Tartumaa Muuseum, Pikk 2,61505 Elva, Eesti; mveldi@msn.com

Piirid looduses ja kultuuris. Arheoloogia-geograafia kevadkool 19.-20.03.2005, Taevaskoja

19.-20. märtsini toimus järjekordne arheoloogia kevadkool, seekord arutleti-diskuteeriti koos geograafidega. Seminari eesmärk oli kombata piire looduses ja kultuuris, leidmaks kahe teadusharu kokkupuutepunkte, ühisjooni ning ka erinevusi.

Arheoloogia on alati aktiivselt otsinud koostöövõimalusi teiste teadusharudega, et jõuda tõepärasema ja adekvaatsema minevikukujutamiseni. Ei ole mõtet leiutada jalgratast, kui keegi teine on seda juba varem teinud. Avatud mõtlemine ja teiste teaduste meetodite ning kontseptsioonide arutamine ja vaatlemine võivad arheoloogiat tunduvalt paremini edasi arendada kui vaid omakeskis pusimine. Ka toimunud seminar näitas, et sarnaseid teemasid on võimalik lahata väga erinevalt. Paratamatult võib ühe teadusharu sees tekkida omamoodi vaakum, kus teadlased mõtlevad ja kirjutavad enam-vähem ühesuguses suunas ning uute vaatenurkade leidmine muutub üha keerulisemaks.

Paar kuud enne seminari korraldamist püüdsime geograafidega välja mõelda mõned kattuvad teemad. Üllatusena selgus, et mõlemale teadusele huvipakkuvaid probleeme on palju: maastik, inimene, nende omavaheline suhe, keskkond ja selle mõjutused, täppisteaduslikud uurimismeetodid, maastiku ja inimese poolt tekitatud piirsituatsioonid jne. Esimesel kohtumisel tekkis (tõstatati) ka muinsuskaitse ja looduskaitse omavahelise koostöö küsimus, kuid seminaril sellele enam keskenduda ei jõutud.

Kevadkooli eesmärk oli luua õhkkond, kus ettekannete käigus tekiks viljakaks diskussiooniks hea atmosfäär. Osaliselt see ka õnnestus ning loodetavasti jäi igal osavõtjal vähemalt üks hea mõte peas helisema.

Seminari üldtemaatika lähtus looduslikest ja antropogeensetest piiridest. Kus ja kuidas võib piire näha? Mis põhjustel on mõned alad piiratud? Kes neid piirab? Võib-olla on piirid ainult uurija enese peas? Suures osas lähtusid ettekanded etteantud teemast ning probleemidele prooviti läheneda piirsituatsioonikeskselt.

Kõige otsesemas mõttes käsitles looduse ja inimese koosmõjul tekkinud piire inimgeograafia doktorandi Taavi Pae ettekanne "Mõningaid tähelepanekuid Eesti- ja Liivimaast", kus otsiti selgitusi teravatele kontrastidele Lõuna- ja Põhja-Eesti vahel. Kahe piirkonna erinevused ilmnevad näiteks kirikaedadesse matmises, erinevas sümboolikas kirikutornides (Lõuna-Eestis Riia mõjutusena levinud kuke sümbol, Põhja-Eestis pigem rist), erinevates lehmatõugudes (Lõuna-Eestis eesti punane, Põhja-Eestis eesti holstein), arhitektuuris (Lõuna-Eestis levinud savi, Põhja-Eestis paekivi), keeles ning lõpuks ka looduslikus aluspõhjas (Lõuna-Eestis devon, Põhja-Eestis silur), mille piir kattub enam-vähem Liivimaa ja Eestimaa kubermangude piiriga ning seeläbi võimendab erinevusi veelgi. Seega võib Põhja- ja Lõuna-Eesti kultuurilist eripära osaliselt tõlgendada isegi geoloogilise 
aluspõhja erinevusega, kuid kas see kahe piirkonna elanike mentaliteeti ka nii põhjapanevalt on muutnud, jääb igaühe enda otsustada.

Kontrastide otsimisele ja analüüsimisele keskendus ka inimgeograafia doktorant Anu Printsmann, kes vaatles Kohtla-Järve õõnsate maastike ilu ja valu, seda läbi erinevate inimsaatuste ja elulugude. Kohtla-Järve sündis alles aastal 1946. Põlevkivi toel tõusis linn heale majanduslikule järjele, kuid juba 60 aastat hiljem vaevleb kunagine ihaldatud elu- ja töökoht kriiside käes. Industriaallinna maastiku kontseptsioonil on mitu kihti, neist lähemalt lahkas Printsmann inimeste elulugudesse põimunud mõttemaastikke. Järgnenud diskussioonis kerkis küsimus elulugude hermeneutikast: kuidas näiteks inimese emotsionaalne seisund võib mõjutada tema jutustatud elulugu?

Mõnevõrra teises võtmes vaatles maastikku kartograafia magistrant Edgar Sepp, kes proovis õietolmuanalüüsi põhjal modelleerida muistset maakasutust Rõuge Tõugjärve ümbruses. Antud juhul jäi lahtiseks probleem, kuidas seda kõike oleks võimalik kasutada minevikust reaalse pildi andmiseks. Ettekande tulemusena tekkinud arutelus ilmnesid ka mõned erinevused täppis- ning ühiskonnateaduslikes mõttemallides ja metoodilises lähenemises. Kui oleks võimalik ühendada täppisteaduslik mudel allikaid võrdleva ning tõlgendava meetodiga, oleks tulemus kõige optimaalsem.

Mineviku maakasutuse probleeme käsitles ka geoinformaatika magistrandi Helle Koppa ettekanne "Muutused maastikus ja kaartides: Vana-Kuuste 1800-1995", kuid erinevalt Edgar Sepast keskendus ta rohkem ajaloolisele ajale, kasutades selleks erinevaid kaarte, statistilisi andmeid, arhiivimaterjale ning ka kirjanduslikke allikaid. Veel pooleli oleva uurimuse kaugemaks eesmärgiks oli vaadeldava piirkonna kaartidest luua aegrida ning kasutada seda mineviku maakasutuse tõlgendamiseks. Ettekande diskussiooni osas ilmnes, kui kompleksselt on võimalik maastikku mõtestada. Mis vahe on loodusmaastikul ja kultuurmaastikul? Kas tänapäeva Eestis on üldse võimalik nende kahe vahele piiri tõmmata? Kuidas mõjutavad teed ja raudteed muutusi maakasutuses ning arusaamist maastikust?

Teatud mõttes modelleerimiseks võis pidada ka arheoloogia magistrandi Mari-Liis Rohtla ettekannet "Esemelise leiumaterjali piirkondlikud eripärad", milles ta keskendus tüpoloogiliselt sarnaste esemete levikule ning võimaliku päritolu tõlgendamisele, seda peamiselt Kristina Creutzi ja Anna Bitner-Wróblewska tööde põhjal. Ettekandele järgnenud arutelus jäi kõlama mõte, et esemete tüpoloogiliste levikukaartide koostamine on arheoloogiateaduses igandiks ning kätkeb endas mitmesuguseid probleeme, kuid ilma neid koostamata ei ole siiski võimalik originaalset interpretatsiooni üles ehitada. Teiseks peamiseks küsimuseks oli, millega seletada samaaegsete esemete leiutihedust või leiutühjust erinevates piirkondades.

Eraldi võib käsitleda kolme ettekannet, mis kõik arutlesid piiratud ala kontseptsiooni üle: Piret Pungase "Kiigekohad Eesti maastikes", Mari Lõhmuse "Kammkeraamikakultuuride matused ning nende paiknemine ruumis" ja Karin Vimbergi "Lipa ringvall-linnus".

Inimgeograafia doktorant Piret Pungase kiigekohtade analüüs lähtus pigem tänapäevasest kui etnograafilisest ja rahvaluulelisest ainesest, andes seetõttu rohkem sotsiaalteaduslikku kui ajaloolist infot. Kiigekohtade kasutuses ilmnesid mõned väga huvitavad seigad, näiteks kiigekoha ebapopulaarseks muutumine pärast õnnetust või muud halva iseloomuga juhtumit (kui noored tulevad kiigele narkootikume tarbima). Samas käis läbi ka mõte, et kiigekoht kui noorte sotsiaalse lävimise seisukohalt oluline paik on kaotamas oma endist tähtsust, seda eriti massimeedia ning virtuaalsete suhtlusvõimaluste tõttu. Erinevusi kiigekohtade kasutamises võib näha ka nõukogude aja ning taasiseseisvunud Eesti vahel: okupeeritud Eestis aitas kiikumise traditsioon sarnaselt laulupidudele teatud mõttes hoida rahvuslikku identiteeti, kuid viimase 15 aasta jooksul on kiigekohtadest saamas peamiselt turismiobjektid ning peopaigad.

Kevadkooli ainsa kiviajauurijana rääkis arheoloogia üliõpilane Mari Lõhmus kammkeraamikakultuuride matuste paiknemisest ruumis, analüüsides asulasse ja asulast välja matmise erinevaid tõlgendusi ning nende taga olevaid võimalikke muutusi kiviaja inimese ideoloogilises maailmavaates. Hämmastaval moel tundusid kiigekohad ja kammkeraamikakultuuride matused omavahel ideeliselt seotud olevat. Mõlemad haakuvad inimasustusega väga tihedalt, kuid on samal ajal ruumiliselt piiratud ning kannavad teatud tabulist ja kultuslikku laengut. Üldise arutelu käigus selgusid ka mõistete riitus ja rituaal erinevad tähendusväljad, millest esimene on osa viimasest.

Arheoloogia üliõpilane Karin Vimberg keskendus oma ettekandes Lipa ringvall-linnusele, mille interpreteerimine on rohkem kui problemaatiline. Vaid $2 \mathrm{~m}$ laiuse ja vaevalt $1 \mathrm{~m}$ kõrguse kivivalliga 
piiratud ala on seni tõlgendatud varase eelrooma rauaaegse linnusena, kuigi kivivallid on ilmselgelt liiga tagasihoidlikud, et omada tugevat kaitsefunktsiooni. Sarnaseid ringvalliga ümbritsetud alasid on leitud ka Skandinaavias, kus osa uurijaid on omistanud neile kultusliku tähenduse, kuid analoogseid mereäärseid muistiseid on vaadeldud ka sadamakohtadena.

Soovimata vähendada mainitud kaheksa ettekande tähtsust, peab tunnistama, et kevadkoolis jäi esitamata kõige olulisem: kahe teaduse eluolu ning võimalikke ühiseid suundumusi tutvustav referaat. Seda kompenseerisid küll osaliselt üldine diskussioon laupäeva õhtul ning mitteametlikud silmast silma vestlused, kuid ikkagi jäi puudu süvitsi mitmeteaduslikkusesse minevast mõttevahetusest.

Koosolemisel esitamata jäänud ettekande sisu haakub hästi kevadkooli üldise temaatikaga. Piirid ei eksisteeri ainult riikide või maakasutustüüpide vahel. Ennast piiritlevad ka teadusalad. Institutsionaliseerumine kui distsipliini defineerimine on põhjustanud teadustevahelise isolatsiooni, mille tagajärjel rühmituvad teadlased uurimissuundade kaupa ja eelistavad suhelda ning mõtelda enda eriala piires. Antud protsess on laiemalt tuntud akadeemilise hõimkondlusena (nt Clark 1987; Ylijoki 2000). Võib öelda, et nii on läinud ka geograafia ning arheoloogiaga Eestis - küll kogemata ning õnneks mitte täielikult. Arheoloogia on sattunud humanitaarsesse filosoofiateaduskonda, kui geograafid jagavad maja loodusteadlastega. Erinevates ringkondades liikudes on aga jäädud võõraiks, seda eelkõige organisatsioonilisel tasandil. Täielikust isolatsioonist on asutusi hoidnud vaid mõned üksikud piiririkkujad-entusiastid - käputäis tudengeid, maastiku-uurijaid, geoinformaatikuid.

Nagu Taevaskojas selgus, on teineteise tundmiseks siiski põhjust. Koostöö oleks kasulik mitmel eri tasandil. Esiteks praktiliste nõuannete osas. Suurt huvi tunti geograafia erinevate leivaalade nagu näiteks GIS-i või kartograafia vastu. Sõltuvalt arheoloogide huvist oleks võimalik korraldada erinevas formaadis kursusi või seminare loodus- või inimgeograafia meetoditest. Teiseks on teoreetilisi või metodoloogilisi probleeme, mida teise teadusüksuse vaatenurk aitaks vaadelda uue nurga alt. Sedasorti vestlused tekkisid näiteks seoses muldade ja kultuurkihiga. Eriti kerkis üles küsimus piiride suhtelisusest: looduses ei pruugi piirid olla alati selged, vaid sujuva üleminekuga ühtede omadustega alalt teisele.

Omalt poolt pakub mõned potentsiaalsed uurimissuunad välja ajaloogeograaf Malcolm Wagstaff (1983): sotsiaalsete protsesside ning ühiskonnaga tegelevate teaduste üks fundamentaalseid küsimusi on sotsiaalse rühma äratundmine. Kuigi inimgeograaf saab tihtipeale toetuda usutavatele statistilistele näitajatele, näiteks jõukus või amet, peab ta mõnikord nagu arheoloogki kasutama materiaalseid tõendeid: näiteks majade välisilme või muu usutavasti kultuurilist väärtust omav objekt. Teise ühise huvina märgib Wagstaff ära ühiskonna tegevuste ruumilise organiseerumise ning kuidas väliste tõendite kaudu saab määrata asustusmustreid ja -piire. Mõlemad teadused jagavad huvi ühiskonna võimusuhetest, olgu need siis majanduslikud, sotsiaalsed või poliitilised.

Veelgi tihedam teaduslik lõimumine aitaks süüvida sügavamatesse teoreetilistesse ühendkohtadesse, kus ruumilised ning artefaktide tõlgendamise meetodid moodustavad ühisosa.

Last but not least: ühessegi teaduslikku vormi mitte mahutatav maastiku-uurimine kuulub võrdselt nii geograafide kui arheoloogide repertuaari. Loodetavasti toimub siingi positiivne areng, kuna hetkel on see kõige perspektiivikam kahe distsipliini ühisosa.

Kokkuvõttes läks kevadkool edukalt. Sõltumata sellest, kas tegu oli vaid ühekordse äratundmise või intensiivsema koostöö algusega, saadi aimu teineteise tegemistest. Jääb üle vaid loota, et sedasorti vahva rahvahulk taas üheskoos filosofeerimiseks põhjust leiaks!

\section{Kasutatud kirjandus}

Clark, B. R. 1987. The Academic Life. Princeton: The Carnegie Foundation for the Advancement of Teaching.

Wagstaff, J. M. 1983. Geography, archaeology and environment. - The Geographical Journal, 3 (vol. 149), 323-332.

Ylijoki, O.-H. 2000. Disciplinary cultures and the moral order of studying: a case-study of four Finnish university departments. - Higher Education, 39, 339-362. 